\title{
THE BEGINNINGS OF BIBLE MISSION OF THE BRITISH AND FOREIGN BIBLE SOCIETY IN EARLY NINETEENTH CENTURY HUNGARY
}

\author{
OTtó PECSUK
}

Károli Gáspár University

\begin{abstract}
The paper examines the very beginnings of Bible Mission in Hungary within the Habsburg Empire in the first part of the nineteenth century. It divides the first thirty years into two major epochs: the one before Gottlieb August Wimmer, Lutheran pastor of Felsőlövő (Oberschützen) and agent of the British and Foreign Bible Society (BFBS) and the one characterized by his work until the revolution of 1848. In the paper, I summarize the main obstacles of Bible Mission both political and religious as well as the main achievements and formations of policies and practices that still define Bible Mission of the Bible Societies in all around the world. The work of BFBS in Hungary in this period was also intertwined with the formative period of the Budapest Scottish Mission, a topic that I also touch in the paper.
\end{abstract}

KEYWORDS: Bible Mission, Bible Societies, Gottlieb August Wimmer, British and Foreign Bible Society, Christianity in the Habsburg Empire

I must open my paper with an apology. It should be highlighted from the start that I am a Biblical scholar as well as a Bible Missionary of the Hungarian Bible Society and by no means a church historian.

Therefore, I am not researching the events and personalities of this period from purely a historical point of view but rather like someone who is involved in the Bible Mission of the 21 st Century Hungary.

I am more interested in the dynamics of the key players, in the factors that drove Bible Mission forward in those years. While researching for my paper, I was looking for the very roots of the mission that I am standing in now. First and foremost, I will rely on the Annual Reports of the British and Foreign Bible Society and try to reconstruct the real picture behind the often subjective reports of the travelling correspondents and colporteurs of the Society to its Committee.

* $\quad$ OTTÓ PECSUK (PhD 2007, Budapest) is Associate Professor of New Testament Theology at the Károli Gáspár University of the Reformed Church in Hungary, also serving as General Secretary of the Hungarian Bible Society. Email: otto.pecsuk@bibliatarsulat.hu. 


\section{The Pre-Wimmer Period}

We are not exaggerating when we call the period before 1837 the 'Pre-Wimmer period'. Later it will be clear why I say this. In the first three decades following the establishment of the BFBS in 1804, Hungary and Hungarian Bibles are only mentioned sporadically in the reports of the Society. John Eibner mentions a certain Johann Tobias Kiesling (Eibner 1983: 39; Mecenseffy 1958: 29-70), a travelling tradesman from Nürnberg who received grants from the Society for the distribution of Christian literature and Bibles among the poor in various parts of the Habsburg Empire, but we do not know how extensive his work was (I have not found any trace of it in the Reports). The next name concerning Bible Mission is Fredrick Leo (Eibner 1983: 39) a French colporteur who informs the Committee of the fact that over one million Protestant Christians live in Hungary and most of them lack not only Bibles but any other Christian literature. The Committee is deeply moved by the reports on the dire economic and religious situation of this population. Leo also mentions the warm reception he and his Bibles enjoyed in Pressburg (now Bratislava and Pozsony) upon his visit in the town:

I was never in all my life received with such real delight, as when I made my appearance at Pressburg, with the Bible in my hand. The Bibles and Testaments which I could spare for them at that time were all sold the next day, with the exception of a few which were furnished to the very poorest gratuitously (Annual Report of the BFBS 1812: 236).

There, in Pressburg he meets some people who would become the first pillars of the BFBS mission in Hungary for the next couple of years. Five Lutheran Professors at the local Lutheran Lyceum, Daniel Stanislaides, Paulus Bilnitza, George Palkovic, Stephanus Fabri and Johann Grosz together founded ( $A n$ nual Report of the BFBS 1816: xiii) the so-called Hungarian Bible Institute in August 1811, under the patronage of Baroness de Zay (Canton 1904:42). The four Protestants superintendents were notified and called for support of this work. Surprisingly, not only Protestant pastors but also the Catholic clergy were encouraged to send Bible orders and subscriptions to the Institute ( $A n$ nual Reports of the BFBS 1811-13: 238ff). The aim was twofold: first to help the fight of the Protestant Churches for religious freedom in the situation of a growing religious and political oppression by the Catholic clergy and aristocracy in the first decades of the 19th century (Bíró et all 1995: 224-226) and second, to promote 'orthodox' Protestant theology and puritan spirituality among the Lutherans and the Reformed, both denominations-at that time-living under the spell of rationalistic thinking and Enlightenment Philosophy. According to the reports (Reports of the BFBS 1817: 222-223) of Professor Stanislaides, in the first few years of Pressburg Bible Institute, they were busy with distributing Chech, Hungarian and German Bibles (500 
copies) and with printing Wendisch New Testaments. In preparation for the 300th anniversary of the Reformation, they decided to multiply their efforts in distributing Luther-Bibles (Owen 1816: 94).

From this early period, it is worth to mention two diplomatic efforts of the leading figures of the BFBS. Both were promising and eventually ineffective at the same time. In 1816 Dr Carl Steinkopff, Foreign Secretary and Lord Teignmouth, President of the BFBS had a meeting with Archdukes Johann and Ludwig, who were then on an official visit to England. In the same year, Robert Pinkerton, then a traveling agent of BFBS visited Vienna where he met Chancellor Prince Metternich. Pinkerton argued persuasively for the establishment of a Vienna-based Bible Society. Pinkerton knew the Chancellor's conservativism and love for authoritarian politics, so he reasoned this way:

In every country where Bible Societies have been founded... the churches have been better frequented, the ministers of religion more sought after and the desire of wickedness and immorality lessened among the people. The union of all confessions also, in the cause of the purest and noblest Christian beneficence has widely diffused charity among mankind and powerfully promoted the happiness of individuals, of families and of nations (Reports of the BFBS 1817: 94-95).

Most probably Metternich only faked his distinguished interest and he was merely seizing the opportunity to gather some firsthand information on the operation of the Bible Society movement which by then had led to the setting up of so many 'sister' Bible Societies all around Europe. Metternich must have been convinced that the Bible Societies were promoters of the Gospel, therefore at the same time adherents of the Protestant idea of liberty and a potential threat to any authoritarian regime. Not surprisingly, on the 23 December 1816 a royal rescript was issued banning all distribution and sales of Christian literature and Bibles as well as any attempts to establish a Bible promoting Society or Association:

Considering that the London Bible Association had caused the establishment of several affiliated societies... His Sacred Majesty has been graciously pleased to ordain that care be taken that printed copies of the Bible be not circulated gratis, or at a low price by such foreign Associations... nor the establishment of a Bible Association be allowed (Eibner 1983: 42).

The Pressburg Bible Institute was with immediate effect dissolved, Bibles and New Testaments confiscated, ongoing printing projects of Slavonian, Hungarian, Wendish and German Bible translations suspended (Reports of the BFBS 1818: 77 and 297). For several years, Bible mission was put on a halt in Hungary, especially since the prohibitory order was reinforced in 1822 (Eibner 1983: 42). According to the Reports of the BFBS from 1824 (Reports of the BFBS 1824: 67), in his Frankfurt visit, Rev. Dr. Steinkopf met some people 
who were still engaged in effective Bible distribution in Hungary, but there was no official and organized missionary activity (the costs of BFBS related to Bible distribution in Hungary was only 94 Pounds, see Reports of the BFBS 1827: 53). Between the years 1816 and 1835, the operation of the BFBS was characterized by either spontaneous 'guerilla mission' meaning individuals casually involved in obtaining and distributing Testaments and Bibles or explicit underground actions. This modus operandi was uncharted territory for the BFBS. The Bible Society movement since the beginning and even today has always tried to find the legitimate ways to distribute Bibles in every country and territory, regardless of whether this meant being compromised in the eyes of Christians living under political and religious pressure. The closure of the Pressburg Bible Institute found the Bible Society unprepared for these new and creative ways of illegal Bible mission. For a start, when John Mayers, chaplain to the English-speaking Protestants in Trieste was engaged in Bible smuggling through the port of Fiume, he was soon banished from his area of operation. Another key player of this short 'grey zone period' was Rev. J. M. Müller from Württemberg. Through his many contacts among Austrian Protestants, he managed to visit Western Hungary (Győr, Székesfehérvár, Alcsút, Buda-Pest) and to engage in semi-legal Bible distribution activity. He even tried to convince the wife of Palatine Joseph, Maria Dorothea to publicly support the work of the Bible Society. Maria Dorothea was soon to become the single most influential royal supporter of both the work of the Bible Society and of the Scottish missionaries in our period, but at this stage, she could not create any unnecessary tensions with her royal kins over the support of an officially banned organization. As a result, and probably against her best emotions, she had to turn down the request of Rev. Müller (Eibner 1983: 43). Nevertheless, Müller managed to find partners in the unfolding Bible mission. He and his coworkers set up and followed specific rules for the distribution which are still in place among Bible societies today: 1. People capable of paying the total price of the Bible need to pay for it. 2. Those unable to pay the full price are eligible for a discounted price. 3. People with no or little income (soldiers, inmates, hospitalized) or those who live in extreme poverty can receive the Bible for free (Reports of the BFBS 1833: xxvi). Müller and his co-workers creatively distributed books that they had either imported from Germany, had purchased from existing stocks of local booksellers or commissioned to be printed by local printers. Their work was constantly threatened by the police and the secret service of the Habsburg Empire. A door was opened unexpectedly when Müller agreed with Professor János Somossy at Sárospatak: he had just finished his revision of the Károli translation, and the printing process was about to start. Müller purchased the first 2,000 copies of the print-run of both the New Testament and the full Bible. Unfortunately, the authorities that for a long time have kept Müller on their watch list 
discovered his ties with the Sárospatak College and its Printing Press. Therefore, both Müller and his whole operation was compromised and eventually cancelled (Eibner 1983: 44). Müller had to leave the country. Bible Mission as such has not stopped, though. A certain Mr. Eisner from Berlin somehow managed to distribute 250 Bibles, and 250 New Testaments in Hungary and the printing press at Sárospatak also produced 2000 Hungarian Bibles (Reports of the BFBS 1838: xxxviii).

\section{The Wimmerian Period}

In 1937 a Lutheran Pastor from Oberschützen (Felsőlövő), Gottlieb August Wimmer (Eibner 1983: 44) asked Dr. Pinkerton and the Committee of the BFBS to consider his application for the job vacant after Mr. Müller's expulsion from Hungary. Wimmer was not unknown to the Board of BFBS: He has been already in a working relationship with the Tract Society since 1835 (Eibner 1983: 45). Dr Pinkerton gave the Committee a very favourable characterization of him:

A man of enterprising spirit-47 years of age-sharp intelligence and very zealous for the service of evangelical truth; [he] has a parish of 4,000 souls-has been twice denounced to the Imperial Government by his Neologian Brethren as a Mystic; but tho' his case has each time reached the Cabinet of the Emperor, he has been acquitted... (Eibner 1983: 45).

The Committee accepted his application and first entrusted him with a smaller number of books, but as he proved to be worthy of the trust, they soon gave him 3,500 Bibles and 8,300 New Testaments (Reports of the BFBS 1842: xxix). In many ways, he continued the underground operations of his predecessor, but unlike Mr. Müller, he could rely on his good relations with high profile supporters like Maria Dorothea and Count Gustáv Batthyány. Wimmer did not have an easy task. In his reports to the Committee of the BFBS, he constantly complained about the religious indifference of the leading social elites in Hungary, the economic and spiritual misery of the lower classes but first and foremost about the hostility and skepticism of his own rationalistic and disillusioned colleagues, pastors of both the Reformed and the Lutheran Church. Nevertheless, he had reasons to report on some positive developments as well. The geographic location of his base, Felsőlövő, and its proximity to Kőszeg proved to be an advantage when it came to acquire books from the Reichardt Printing Press (operating in Köszeg), thus saving on the transportation and custom costs, also reducing the chance of confiscation by Imperial censors (Eibner 1983: 45). He also praised God for lighting the fire for the Holy Scriptures in the heart of the simple and poor people of Hungary, peasants, tradesman and especially soldiers (Reports of the BFBS 1843: xlvii-xlviii), who were willing to give their last krajcárs for the Bibles 
even if they had nothing to eat for that day. He tells a story of a distribution trip where all 3,000 copies of his pocket-size New Testament were immediately bought by soldiers, so rushing that any further copies had to be distributed under the condition that only literate solders can buy them. On that day, hundreds of soldiers started to learn reading from their literate comrades (Reports of the BFBS 1844: xlviii). His honest admiration towards Hungarians as Bible-loving people has grown steadily. Wimmer recruited about 200 colporteurs and local Bible distributors (from areas as far as Bánát, Slovakia, Nagyvárad), mostly Protestant pastors who worked under his supervision (Reports of the BFBS 1842: xxxi). In the first five years of his service, Wimmer has travelled extensively, distributed ca. 23,500 Hungarian, 20,000 Czech and 11,000 German Bibles (Canton 1904: xxx-xxxi) and produced a net income of 20 thousand forints from Bible distribution only-a most remarkable achievement in a seriously under-developed country like Hungary in those times. As John Eibner summarizes, 'these resources, coupled with Wimmer's tremendous energy and organizational abilities, proved to be a dynamic combination yielding results which far outstripped those of the Pressburg Bible Institute or Pastor Muller' (Eibner 1983: 46).

In 1840 he visited England, where he did not only raised funds for his future work but also got inspired by examples like Elisabeth Fry (Rose 1980) to reach out to inmates in prisons and improve hygienic and educational conditions among his parishioners in Felsőlövő. It was in the early 1840ies that Wimmer established contact with the Scottish missionaries and their work in Buda-Pest. The history of the Scottish Mission in Buda-Pest and the involvement of the Church of Scotland and the Free Church of Scotland in the mission and schooling among the Jewish population of Pest is a well-researched area (Eibner 1983: 47 note 24) mainly due to the research of Kovács Ábrahám (Kovács 2006) and there is no time here to enter into details of the subject. But it is worth to stress the strong relationship between Wimmer's Bible mission and the honest evangelizing work of the Scottish missionaries among the Jews. In his reports, Wimmer encouraged the Committee to consider printing more Hebrew Scriptures which could be easily distributed among the urban Jewish population in Pest (Reports of the BFBS 1843: xlvii-xlviii). His hopes were reasonable, in subsequent years over 2,000 Hebrew Scriptures were printed in Kőszeg under his administration, and the costs were evenly divided between the Free Church of Scotland and the BFBS (Eibner 1983: 4950). But not only the enlightened Jews were uncharted territory for Wimmer: he was convinced that both Roman Catholics and Orthodox (he estimated their number around one million in Hungary) could be made open to the Word of God with a proper missionary approach It was his personal experience that even in the villages and towns where the population was predominantly Catholic, he and his Bible were received with joy and enthusiasm 
(Reports of the BFBS 1843: xlix). [Unfortunately, as far as the global situation is concerned, he proved to be a false prophet on this: Pope Gregory XVI soon issued his Inter praecipuas encyclical on 8 May 1844, condemning the work of the Bible Societies. Gregory sees himself a worthy follower of previous popes condemning the perilous work of the Bible societies: 'Leo XII continued the battle against the biblical societies with an encyclical letter addressed to all the bishops of the Catholic world, published on May 5, 1824, and Pius VIII did the same in an encyclical letter published May 24, 1829. And lastly, We who, though unworthy, have succeeded to his place have taken great pains to remind the faithful of the ancient laws concerning vernacular translations of the Scriptures.' (http://www.papalencyclicals.net/Greg16/g16inter.htm, last view: 20.11.2018)]

On the one hand, after 1840 life in the Catholic Habsburg Empire became gradually easier for Protestant missionaries like Wimmer, but on the other hand, more liberalism in the religious matters walked hand in hand with agitated political liberalism and social unrest. Distribution figures started to drop. Wimmer explains the reasons in his correspondence with the Committee of BFBS (Eibner 1983: 51):

The present political excitement is becoming daily more injurious to a religious life. The ungracious dismissal of the Diet and its portentous conclusion have caused a feverish commotion and agitation throughout the country, the consequences of which may be anticipated. ...Times and circumstances like these are very unfavourable for the promotion of religion among any people.

These circumstances in 1844 worsened by an unusually cold winter made almost impossible to travel on carts between isolated villages (Reports of the $B F B S$ 1845: lxxiii). At the same time, Slovak nationalism was also on the rise. Wimmer, who had always happily distributed the Bible in all languages of the Empire without any nationalistic favouritism, had to realize that Slovaks did not welcome his Bibles in Czech:

What particularly seems to deserve the attention of the Bible Society is the singular feature in which the Bohemians (Slovaks) are placed. These people have been instigated by the violent proceeding of their clergy to assume a position in their national character positively opposed to that of the Hungarians... The clergy are beginning to give up the use of the classic Bohemian (Czech) in their addresses from the pulpit... They condemn the Bible and all religious publications that are not written in the dialect of the people (Eibner 1983: 51).

Nevertheless, in 1845 he saw new territories waiting to be discovered and included into his impending distribution journey in 1846: Szabolcs, Bihar, Heves and Borsod, where-according to his own words-hundreds of congregations were still waiting without Bibles (Reports of the BFBS 1846: lv). 1846 
was the year of a mysterious potato disease, and-just like in Ireland-a severe famine followed. People suffered, social unrest worsened, the rationalistic clergy could not help the misery of their flock and naturally, the figures of Bible distribution also dropped, except for the rising need for Hebrew Scriptures in the Scottish Mission (Reports of the BFBS 1847: lii).

The revolution of 1848 did not find Wimmer with idle hands. He was planning to set up new Bible depots in Pressburg (Pozsony), Debrecen, Kolozsvár, Brassó and Zagreb. When the fights started in the spring of 1848, his base in Oberschützen (Felsőlövő) was threatened by Croat militia troops instigated by the Habsburg Court. The same year in August he travelled to London, together with Dr Pinkerton, apparently as a colporteur of the BFBS but also on a secret mission, as agent of Kossuth Lajos with the task of purchasing weapons and a banknote press for the revolutionary Government (Eibner 1983: 52 and Reports of the BFBS 1849: 1x). Upon his return, he joined the Hungarian National Guard and participated in the unfolding freedom fight of Hungary. Soon an order of arrest was issued against him. He had to flee, and he found refuge in Switzerland. Formal Bible Society mission was once again stopped in Hungary, until the end of the war, which followed the surrender at Világos in August 1849 Reports of the BFBS 1850: 1). The aftermath belongs to the new period in the history of Bible mission in Hungary, and it may be the subject of another paper.

\section{Conclusion}

The history of early Bible mission of the BFBS in Hungary in the first part of the nineteenth century seems to be characterized by enthusiasm and trust on the part of the western actors, heroism and creativity on the part of the local actors. Outstanding personalities and God-fearing Christian individuals tried to overcome the oppressing and disillusioning circumstances of a semi-colonial country cursed with poverty, short-sighted political leadership and a politically hyperactive but spiritually paralyzed Church. The achievements of Wimmer and the Scottish missionaries in Buda-Pest are outstanding and humiliating at the same time. They teach us the lesson that harsh circumstances and lack of understanding from the contemporaries are never an excuse for idleness.

\section{Bibliography}

Annual Reports of the BFBS (1812-1849) London.

Bíró B, Tóth V (1995) A magyar református egyház története. Sárospatak. Canton W (1904) The Story of the Bible Society. London: John Murray. Eibner JV (1983) British Evangelicalism and Hungary, 1800-1852. Journal of the United Reformed Church History Society 3(2): n.p. 
Kovács Á (2006) The History of the Free Church of Scotland's Mission to the Jews in Budapest and Its Impact on the Reformed Church of Hungary 1841-1914 [Studies in the Intercultural History of Christianity No. 140]. Frankfurt am Main: Peter Lang.

Kovács Á (2009) Protestáns biblia- és iratterjesztés kezdetei, a zsidóság és a Habsburg udvar Magyarországon: 1811-1851, I. Református Egyház 61(2): 34-41.

Kovács Á (2009) Protestáns biblia- és iratterjesztés kezdetei, a zsidóság és a Habsburg udvar Magyarországon: 1811-1851, II. Református Egyház 61(3): 63-67.

Mecenseffy G (1958) Der Nurnberger Kaufmann Johann Tobias Kiessling und die Österreich. Toleranzgemeinden. Jahrbuch des Gesellschaft für $d$. Prot. in Österreich 74(*): 29-70.

*** (1843) National Library of Scotland, Department of Manuscripts, Minutes of the Church of Scotland's Jewish Committee, no. MS-288-81, July 26.

Owen J (1816) History of the British and Foreign Bible Society, volume 2. London: n.p.

Rose J (1980) Elizabeth Frye: A Biography. London: Macmillan.

Schubert GH (1837) The Life of John Tobias Kiesling. London, n.p. 